\title{
Child Oncology and Hospital Recreation
}

\author{
Conceição de Maria Lima Nascimento ${ }^{1,2}$, Erenice Conceição de Almeida Barbosa ${ }^{3}$, \\ Brunna Rafaella Do Carmo Silva ${ }^{3,4}$, Karoline Queiroz Martins Almeida de Araújo ${ }^{5,6}$, \\ Gilzandra Lira Dantas Florencio ${ }^{2}$, Ana Carla Gomes Canário², \\ Paulo Francisco de Almeida Neto $2,3,4,7$
}

\author{
${ }^{1}$ FCU, São Paulo, Brazil \\ ${ }^{2}$ UFRN, Natal, Brazil \\ ${ }^{3}$ UNINASSAU, Natal, Brazil \\ ${ }^{4}$ FAK, Fortaleza, Brazil \\ ${ }^{5}$ UFPB, João Pessoa, Brazil \\ ${ }^{6}$ UFSC, Florianópolis, Brazil \\ ${ }^{7}$ SBOC, São Paulo, Brazil \\ Email: ceicamln2016@gmail.com, ere.barbosa@hotmail.com, brunnarafaella_1990@hotmail.com, \\ gilzandraflorencio@gmail.com, anacarlacanario@gmail.com, paulo220911@hotmail.com
}

How to cite this paper: de Maria Lima Nascimento, C., de Almeida Barbosa, E.C., Do Carmo Silva, B.R., de Araújo, K.Q.M.A., Florencio, G.L.D., Canário, A.C.G. and de Almeida Neto, P.F. (2019) Child Oncology and Hospital Recreation. Journal of Cancer Therapy, 10, 157-165.

https://doi.org/10.4236/jct.2019.102012

Received: December 22, 2018

Accepted: February 18, 2019

Published: February 21, 2019

Copyright $\odot 2019$ by author(s) and Scientific Research Publishing Inc. This work is licensed under the Creative Commons Attribution International License (CC BY 4.0).

http://creativecommons.org/licenses/by/4.0/

\section{cc) (i) Open Access}

\begin{abstract}
Introduction: Hospital Recreation (HR) aims to reduce disasters caused by hospital admission. Objectives: To expose the behavior of children in cancer treatment $(\mathrm{CA})$ during $\mathrm{HR}$, and to verify which recreational activities generate the most adherence. Methods: The research is an experimental clinical trial of a non-probabilistic and intentional sample, with a quantitative and qualitative approach. Participants were 43 children (both sexes), with CA, admitted to the Pediatric Hospital Oncology Center-PHOC. The mean age of the children in fact was 7.5 years, and the data of mean and standard deviation between parenthood confer with the data of the results found during the research. The study lasted 12 weeks, with 38 sessions lasting 3 hours. Using games of activity: cognitive, manipulative, perceptive, creative and cooperative. Inclusion criteria: 1) being hospitalized in the PHOC, of the city of Natal; 2) being released by the medical team to participate in the activities. Children who were on special care in the ICU were excluded from the study. The behavior of the children was evaluated by the observation matrix proposed by Urie Bonfenbrenner, approached by Krebs and Koller. At the end of the research, an interview was made with patients about the HR experience. Results: In the subjects the molecular behavior showed relevance of $\sim 50 \%$, and the cooperative of $\sim 80 \%$ in relation to $\mathrm{HR}$, and the cognitive activities showed an adhesion index of $\sim 90 \%$. Conclusion: The participants showed greater adherence in the cognitive activities, and the predominance of the molecular behavior in relation to hospital recreation, highlighting the co-
\end{abstract}


operative behavior among the individuals. In this way, the activities of $\mathrm{HR}$ can complement conventional medical treatment.

\section{Keywords}

Ludic Activity, Hospital, Children, Recreation, Playful, Cancer

\section{Introduction}

Hospitalization (HP) is a discomforting experience for adults and children, especially for children, because they end up having to give up childhood moments that will never return [1] [2]. The ludicity through the hospital recreation (HR) comes with the objective of reducing the impacts caused by HP [3]. Studies have shown that stimulating good humor through ludicity and laughter, in addition to improving motor performance [4], strengthens biological immunity [5], and promotes socialization among people who enjoy the games [6].

Playing is something natural from childhood, and should be stimulated in all age groups, and when individuals have this naturalness stolen by a disease, they often isolate themselves and tend to become more socially withdrawn. This can bring consequences negative for emotional health, and the revival of ludicity is an interesting way to reverse such traumas caused due to processes caused by illnesses that lead to HP [7] [8] [9].

The HR is a simple intervention that brings magnificent results, which can change the looks of the parents, the middle team, and the children's patients in relation to the treatment of câncer [9]. For this and other reasons, the literature strengthens the importance of alternative means that bring the ludicity into the hospital environment [10].

A lack of studies with recreation (RC) in children undergoing oncological treatment is observed in the literature. It is already known that RC is beneficial for health [11], and the studies do not expose some accuracy about what type of activity to use to generate adherence and effective participation of patients, and how they behave in relation to the activities developed. And it is important for the health professional who work in the area oncology to have a direction on which activities to use in interventions involving HR. Cased on this assumption and in view of the aforementioned data, this academic article aims to expose the behavior of children in the Pediatric Hospital Oncology Center (PHOC), during interventions with $\mathrm{HR}$, and to verify what types of recreational activity show more adherence.

\section{Methodology}

The research is characterized as an experimental clinical trial of a nonprobabilistic and intentional sample, with a quantitative and qualitative approach [12]. The study participants were 43 children (of both sexes), with several types 
of cancer, who were hospitalized in the public hospital network ofNatal-RN, Brazil, with chronological ages between 3 and $12(7.5 \pm 4.5)$ years, and as criteria for inclusion were adopted: 1) being hospitalized in the public network of the Children's Hospital Oncology Center, in the city of Natal/RN-Brazil, and 2) being released by the medical team for participation in the activities of the present study. Those who were on special care in the ICU were excluded from the research, due to the advancing stage of the cancer. The sample choice took place before we started the research, where a meeting was held with the direction of the hospital and the legal guardians of the subjects of the sample, all the procedures, as well as all the possible benefits and discomfort inherent to the research were informed and it was given the possibility that they would carry out any matter they deemed pertinent; the responsibles present together with the direction of the hospital agreed with the proposal of the present study. The ethics of this research followed faithfully, all the norms imposed by the declaration of Helsinki. The research also answered all the items imposed by resolution $466 / 12$ of the CNS-Brazil, respecting also the international norms of experimentation with humans.

\subsection{Collection Methods and Techniques}

The study lasted 12 weeks and the intervention was performed in 38 sessions of hospital recreation, and each session had 3 total hours of duration, where the behavior of the children was evaluated, through the observation matrix based on the activities and structures interpersonal ecology of humand development proposed by Urie Bonfenbrenner [13] [14], and approached by Krebs [13], and by Koller [14]. The matrix consisted of registering the subjects ' involvement in each recreational activity, where the type of behavioral activity was recorded in numerical values in the face of interventions. The recreation consisted of games of cognitive activity (memory game, domino, puzzle, pmgic cube, bingo, crosshatch, chess, etc.), manipulative (drawing and painting watercolor, ping pong, games seated with ball or equipment that requires manipulation, lego, making letters, etc.), perceptive (bowling game, dance chairs, remain 1, follow the master, mimica, etc.), creativity (confectioning objects using popsicle sticks, clipping and collage of figures, create a song with beats in the body, create a toy with recyclable material, etc.) and cooperative (walk of 3 legs to the finish line, slaves of Jó, competition from which group mounts the fastest puzzle, jokempô in double, etc.) [15] [16]. At the end of the 12 weeks of interventions, they were individually collected through a brief questionnaire following the recommendations of Günter [17], answers from the children about the experience experienced in hospital recreation, the dialogues were recorded through of writing, and analyzed by the researchers involved, thus generating a generalized view on the main common points cited by the subjects participating in the research. The questions made in the interviews were:

1) What do you feel when you are joking? 
2) What activities do you most like to accomplish?

3) What do you do when you have no recreation?

\subsection{Statistical Analysis}

The normality of the data was tested by means of the test in KolmogorovSmirnov, and the assumption of normality was not denied; the data were extracted in the form of mean and standard deviation, and converted to relative values and exposed by means of graphs. The comparison between the types of behavior during recreational interventions was performed using the two-way ANOVA statistical test. The same procedure was adopted to compare the higher frequency and adherence (preference) of children in recreational activities that were offered (cognitive, manipulative, perceptive and creative). For all analyses, it was adopted $\mathrm{p}<0.05$.

\section{Results}

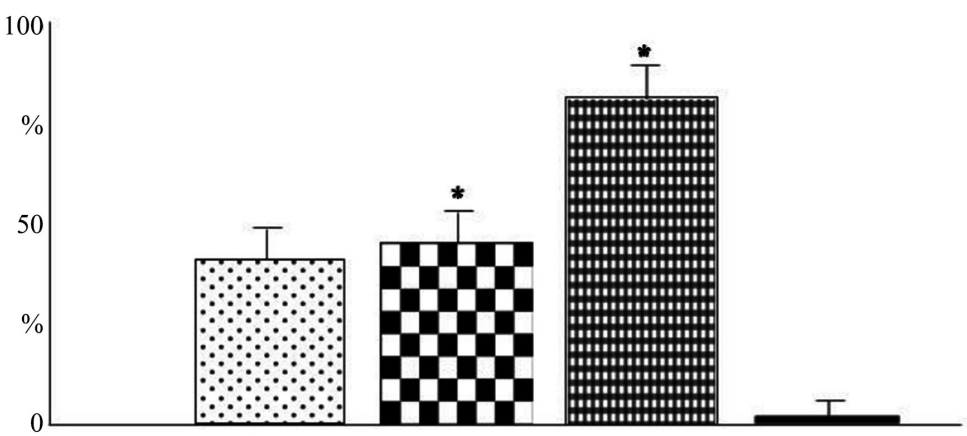

UIIIIU]!I]! Molecular Behavior

㭅三三三三三 Molar Behavior

$\left({ }^{*} \mathrm{p}<0.04\right)$

|||||||||||||| Cooperative Behaviour

Observational Behavior

Figure 1. Behavior of children during recreational interventions.

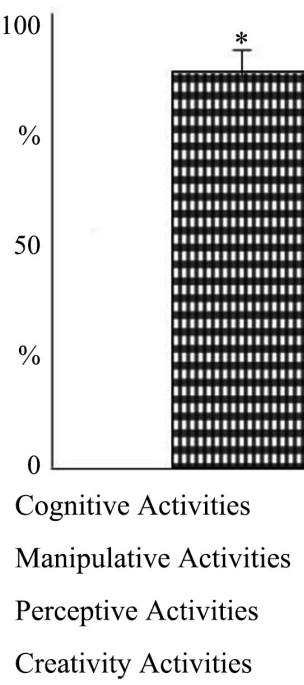

Figure 2. Frequency and adherence of children to types of recreational activities. 
"Based on the responses of the individuals, we observed thatduring the performance of recreational activities, the feeling of joy was unanimous. And that the vast majority indicated preference for cognitive activities that needed cooperationand interaction with other children, such as puzzle, domino, memory game, etc. And when no recreational activity wasperformed the children reported feeling of sadness andidleness, stating that before the recreational interventionsthey did not do any physical or cognitive activity limitingthemselves to having as time only the act of watching television".

Frame 1. Analysis of the responses of the children in relation to the interventions.

\section{Discussion}

The behavioral activities of human development are classified as shown in the following sequence: 1) molar activity (characterized by continuous behavior); 2) molecular activity (characterized by a decotyous behavior); 3 ) cooperative activity (classified by a behavior of interaction and division of tasks or union in the same task with a particular group and or environment); 4) observational activity (characterized by the act of observation, without direct participation) [13] [18].

The results shown in Figure 1 indicate the behavioral activities of human molar and cooperative development, as significant among the participants of the present study. We know that in the Pediatric Hospital Oncology Center (PHOC), children remain often isolated and desolate in their beds during the treatments, which leave them socially and needy in need of attention and group interaction [19]. Ludicity brings with it the act of playing, and this provides the breadth of willingness for interaction through recreation contributing to social, physical and cognitive development, enhancing health improvement [6].

To implement the playful in the area of child hospitalization provides children, to live the childhood that the disease steals them little by little, based on Figure 1 of our results, it is noticeable that the studied subjects wanted to participate in the activities proposals and linked to this was the cooperation, the act of preferring activities that made them need the participation of other children; In the face of the facts is undeniable that the recreation within the PHOC can be a complementary alternative in relation to the intervention model and traditional hospital care [8] [9].

The power of the playful intervention, makes the relatives and even the medical team perceive the positive behavioral change of children suffering from cáncer (CA), Lima Nascimento [20], in a study with child oncology (CO) and recreation, conducted interviews with The medical team of the $\mathrm{CO}$ sector, and with the parents of the hospitalized minors, and unanimously the answers affirmed that after the hospital recreation (HR) The children had significant improvements in mood. This makes them respond better in relation to medical treatment [9].

Every child being diagnosed with the CA, will be subject to radically changing his/her life, having to adapt to the social restrictions, absentions in school, needing to learn to give with the acceptance of colleagues who do not suffer 
from the disease, and will have to learn to trusting a team of people responsible for the treatment that did not have any previous interpersonal relationship, this all messes with the psychological and it is necessary to seek alternative means to relieve these tensions [21].

Garcia [10], corroborates with this thought and emphasizes that it is necessary to use psychosocial means that minimize the fear, anguish and anxiety of children and their relatives, including the professional team who is responsible for the procedures From clinical treatments.

In Figure 2, we can observe the preference of the sample studied in relation to the types of recreational activities proposed by the present study, and the results clearly brought the significant exposure of greater adherence of cognitive activities. In the research of Mota and Enumo [22], also with CO and HR, there was no significant difference in the choice of children among the categories of available games, in relation to our results this fact may have occurred due to the individualities of the groups studied [23], in both researches.

It is noteworthy that regardless of the preference of a particular group or individual, it is important to carry out a brief analysis of the subjects who will use the recreation so that a diversified methodology can be implied, where everyone has the opportunity to participate, in order to promote the alleviation of traumas caused by hospitalization, through the HR, which within this context ceases to be seen as a free time activity, and starts to receive credibility as an integral tool of the treatment where they have for Aims to optimize the clinical interventions and reduce the length of hospital stay [24].

The playful brings joy and relaxation, we know that the fact of being sick in itself already promotes some damage to psychological health, and the fact of being hospitalized besides generating stress, comes to contribute to emotional distress, so it is necessary to provide happiness So that the minors admitted to the PHOC, forget for some moments of the pains that live daily, and do not fall into a state of depression [7] [9]. The result shown in Frame 1 shows that children reported that when there was no HR, they had feelings of sadness and idleness, and that they did not perform any physical activity, but when the HR occurred, the reports unanimously were directed for the feeling of joy, or the welfare was present.

Berk et al. [5], in a study conducted with 52 healthy individuals, studied the neuroimmunologic modulation during and after an intervention that provided them with humor, the intervention consisted of showing videos of comedies, the session lasted 60 minutes, and blood samples were collected to evaluate the immunological indicators in four moments: 10 minutes before the beginning of the film, 30 minutes after the video was started, 30 minutes after the end of the intervention, and 12 hours after the completion of the procedure, the results evidenced the increase in the activity of natural killer cells, with several effects on immunoglobin 12 hours after the beginning of the intervention, in view of this evidence the study suggested that, laughter and good humor, can bring significant benefits to health, may be allied to conventional medical treatment, and therefore 
it is worthwhile to ask ourselves about the effect of positive emotions on debilitated individuals, especially in hospitalized children and diagnosed with CA.

The literature has advocated that the achievement of recreational recreation for hospitalized children should be opportun, because the act of play alters mainly the environment in which they are and approaches the daily children's reality, the ludic assists in the therapy and contribui for the development of positive emotions and feelings, promoting the welfare of patients [3] [22] [25] [26].

The present research found among the difficulties and limitations of the study, the fact that due to the specificity of the public used for many times, during the interventions the children were using probes, or intravenous infusion equipment. And during the production of the text, our difficulty was to find concrete data on the subject, because the literature was scarce in relation to the academic articles that had studied the same subject. Therefore, we suggest the production of more academic works on the topic approached.

\section{Conclusion}

Children with cancer who participated in the study showed a greater adherence to cognitive recreational activities, and indicated that they had a molecular behavior in relation to hospital recreation, arousing a continuous interest in the activities developed, and coupled with this the cooperative behavior stood out, considering that socialization was something lacking in hospitalized individuals being natural to seek group activities to supply such a deficiency. Hospital recreation in child oncology can also be used by health professionals as a complement to conventional medical treatment.

\section{Conflicts of Interest}

The authors declare no conflicts of interest regarding the publication of this paper.

\section{References}

[1] Winnicot, D.W. (1985) A criança e o seu mundo. 6th Edition, Zahar, Rio deJaneiro.

[2] Oliveira, S.S.G., Dias, M.G.B.B. and Roazzi, A. (2003) O lúdico e suasimplicações nas estratégias de regulação das emoçõesem crianças hospitalizadas. PsicologiaReflexao e Critica, 16, 1-13. https://doi.org/10.1590/S0102-79722003000100003

[3] Eisen, S.L., Ulrich, R.S., Shepley, M.M., Varni, J.W. and Sherman, S. (2008) The Stress-Reducing Effects of Art in Pediatric Health Care: Art Preferences of Healthy Children and Hospitalized Children. Journal of Child Health Care, 12, 173-190. https://doi.org/10.1177/1367493508092507

[4] Silva, L.F., Almeida Neto, P.F. and De Araújo, A.C.G.C. (2018) Efeito do lúdico na melhora de habilidades motoras em futebolistas de 12 a 16 anos. Lecturas. Educación Física y Deportes, 23, 40-48.

[5] Berk, L.S., Felten, D.L., Tan, S.A., Bittman, B.B. and Westengard, J. (2001) 
Modulation of Neuroimmune Parameters during the Eustress of Humor-Associated Mirthful Laughter. Alternative Therapies in Health and Medicine, 7, 62-76.

[6] Severino, C.D. and Porrozzi, R. (2017) A ludicidade aplicada à Educação Física: A prática nas escolas. Revista Práxis, 2, 51-58.

[7] Ribeiro, C.A. (1991) O efeito da utilização do brinquedo terapêutico, pela enfermeira pediatra, sobre o comportamento de crianças recém-hospitalizadas. Revista da Escola de Enfermagem da USP, 25, 41-59. https://doi.org/10.1590/0080-6234199102500100041

[8] Mitre, R.M.D.A. and Gomes, R. (2004) A promoção do brincar no contexto da hospitalização infantil como ação de saúde. Ciência \& Saúde Coletiva, 9, 147-154. https://doi.org/10.1590/S1413-81232004000100015

[9] Mussa, C. and Malerbi, F.E.K. (2009) O impacto da atividade lúdica sobre o bem-estar de crianças hospitalizadas. Revista Psicologia-Teoria e Prática, 10, 33-43.

[10] Garcia, I. (1996) Crianças submetidas a procedimentos invasivos e/ou dolorosos: Intervenções psicossociais. Pediatria Moderna, 32, 656-658.

[11] Whaley, L.F. and Wong, D.L. (1999) Enfermagem pediátrica: Elementos essenciais à intervenção efetiva. Guanabara, Rio deJaneiro.

[12] Thomas, J.R., Nelson, J.K. and Silverman, S.J. (2009) Métodos de pesquisa em atividade física. Artmed Editora.

[13] Krebs, R.J. (1995) Urie Bronfenbrenner e a ecologia do desenvolvimento humano. Casa Editorial.

[14] Koller, S.H. (2004) Conversando com Bronfenbrenner. Ecologia do desenvolvimento humano: Pesquisa e intervenção no Brasil, 47-61.

[15] Galvão, T. (1984) Recreação Infantil Hospitalar. Da organização e montagem de um serviço. 2nd Edition, UFRGS, Porto Alegre.

[16] Galvão, T. (1984) Recreação Terapêutica em pediatria. Revista do hospital de clinica de Porto Alegre (HCPA), Vol. 4, Ano IV.

[17] Günter, H. (2003) Como elaborar um questionário (Série: Planejamento de Pesquisa nas Ciências Sociais, No. 1). UnB, Laboratório de Psicologia Ambiental, Brasília.

[18] Roland, D. and Françoise, P. (2001) Dicionário de Psicologia (1ª Edição).

[19] Sikilero, R.H.A.S., Morselli, R. and Duarte, G. (1997) Recreação uma proposta terapêutica. In: Ceccim, R.B. and Carvalho, P.R., Eds., Criança hospitalizada atenção integral como escuta à vida, Editora da Universidade Federal do Rio Grande do Sul, Porto Alegre, 59-65.

[20] Lima Nascimento, C. (1997) Recreação Hospitalar: Uma atenção Diferenciada. Graduada. Monografia. Universidade Federal do Rio Grande do Norte, Centro de Ciências da Saúde, Departamento de Educação Física. Natal.

[21] Eiser, C. (1992) Psychological Consequences of Chronic Disease in Children. International Review of Health Psychology, 1, 145-165.

[22] Motta, A.B. and Enumo, S.R.F. (2004) Brincar no hospital: Estratégia de enfrentamento da hospitalização infantil. Psicologia em estudo, 9, 19-28.

https://doi.org/10.1590/S1413-73722004000100004

[23] Cória-Sabini, M.A. and De Lucena, R.F. (2004) Jogos e brincadeiras na educação infantil. Papirus Editora.

[24] Oliveira, L.D.B., Gabarra, L.M., Marcon, C., Silva, J.L.C. and Macchiaverni, J. (2009) A brinquedoteca hospitalar como fator de promoção no desenvolvimento infantil: Relato de experiência. Journal of Human Growth and Development, 19, 306-312. 
https://doi.org/10.7322/jhgd.19920

[25] De Oliveira, I.C.C. and Francischini, R. (2003) A importância da brincadeira: O discurso de crianças trabalhadoras e não trabalhadoras. Revista Psicologia: Teoria e Prática, 5, 41-56.

[26] Favero, L., Dyniewicz, A.M., Spiller, A.P.M. and Fernandes, L.A. (2007) A promoção do brincar no contexto da hospitalização infantil como ação de enfermagem: Relato de experiência. Cogitare Enfermagem, 12, 519-524.

https://doi.org/10.5380/ce.v12i4.10080 